\title{
Self view of women's bodies and characteristics in early glamour website models
}

\author{
Julián Monge-Nájera' ${ }^{1}$ Karla Vega Corrales ${ }^{2}$ \\ Laboratorio de Ecología Urbana, Vicerrectoría de Investigación, Universidad Estatal a Distancia, 2050 San José, Costa Rica; \\ julianmonge@gmail.com, kantr.vega@gmail.com
}

Recibido 3-XI-2009 Corregido 15-XII-2009 Aceptado 7-II-2010

\begin{abstract}
At least at the public level, conservative societies try to prevent women from exposing their bodies, and women who work as glamour models can be seen as transgressors and can be accused of playing a passive role as "sex objects". In contrast with those views, research shows that preInternet models were active participants who perceived their bodies as a way of obtaining resources and power. In order to examine if the same is true in the age of Internet modeling (i.e. if Internet models perceive themselves as passive or active), and if their career choice was affected by geographic origin (a measure of how conservative their society is), we recorded the origin and self-descriptions that models published during the early period of web glamour sites (2001). Our population was composed of all the American models in the international website Glamour Models, the main website for this type of modeling. Our data does not support the hypothesis that conservative states are underrepresented: rather there were more models from states with larger populations. These models did not present themselves as passive: their self-descriptions stated that they are active and creative, and they openly expressed the limits on the type of work that they accepted. By presenting data from a decade ago, our work serves as a baseline for future studies of how self views of women's bodies and characteristics may evolve in this field.
\end{abstract}

\section{KEY WORDS}

Modeling, glamour, body, perception, roles.

\section{RESUMEN}

Por lo menos a nivel público, las sociedades conservadoras tratan de impedir que las mujeres expongar sus cuerpos, y las que trabajan como modelos de glamour pueden ser vistas como transgresoras o acusadas por otros sectores de jugar un papel pasivo como "objetos sexuales". En contraste con estas opiniones, la investigación muestra que las modelos de la época previa a Internet fueron participantes activas que percibían sus cuerpos como un medio para alcanzar recursos y poder. Con el fin de examinar si lo mismo es cierto en la era de Internet (es decir, si las modelos de Internet se perciben a si mismas como agentes pasivos o activos), y si su elección de carrera se vio afectada por el origen geográfico (una medida de cuán conservadora es su sociedad), analizamos el origen y las auto-descripciones que publicaban las modelos en el período inicial de Internet (2001). Nuestra población se compone de todas las modelos estadounidenses en el sitio internacional GlamourModels, principal sitio web de este tipo de modelaje. Nuestros datos no apoyan la hipótesis de que los estados conservadores estén sub-representados: en realidad, hubo más modelos de los estados con mayor población. Estas modelos no se presentan como pasivas, sino que según su autopercepción se califican a si mismas como mujeres activas y creativas, expresando abiertamente los límites en el tipo de trabajo que aceptaban. Estos datos del 2001 tienen el valor adicional de servir para comparación en estudios futuros.

PALABRAS CLAVE

Modelaje, cuerpo, autopercepción femenina.
Humans perceive their bodies as they "are" (according to the information received from their sense organs), and compare them with how they "should be". How they "should be" is a learned concept (Bordo 1993, Davis 2002) that has both biological and cultural roots (Lucal 1999, Jeffreys 2005). There are many sociological and anthropological views of the human body, views that vary according to the age, sex and social position of the person, among others (Schiebenger 1993, Frost 2001, Gimlin 2002).

Fully cultural requirements for a good body are those that transcend biological requirements, and they can be recognized because they depend on the society. For example, the deformed heads and feet of ancient Mexico and China, respectively, were fully cultural definitions of 
how the body should be. As a result of the omnipresence of patriarchy in human society, the body is frequently seen through a comparison that has the male body as reference, where man is conceived as representing in his body at least five characteristics: force, security, competitiveness, independence, culture and intelligence (Schiebinger 1993, Frost 2001). On the other hand, woman is seen as the incarnation of nature and motherhood, an incarnation that is weak, insecure, incompetent, dependent, immature and incapable of great feats of intelligence or culture (Schiebinger 1993, Cao \& Pérez 1996, Jeffreys 2005).

To retain these and other views, societies control individuals through disciplinary practices that have historically shifted from external controls to self-regulation. Although cultural power may seem like a property of certain individuals or groups, it also is a complex network of noncentralized forces that regulate even the most intimate of personal beliefs and behaviors, and among them, the body is a primary site of social control (Brown 2005).

Social norms may be imposed by the individuals and institutional systems in power, but they are even more importantly enforced by the people; in the words of Brown (2005): "there is no need for physical violence, material constraints. Just a gaze. An inspecting gaze, a gaze which each individual under its weight will end by interiorising to the point that he is his own overseer, each individual thus exercising this surveillance over, and against himself. Attempts to discipline the body by inscribing standards of beauty, perfection, social and sexual 'normalcy', are simultaneously attempts to normalize the subject's class standing".

In anthropology, the body is an active agent, and a contribution of feminist research is the view that the body is a political and social "construct", rather than only a physical reality (Esteban 2004).

The body can also be seen as an agent of change when women can decide what to do with their own bodies. In publicity for example, the femme fatal image shows women who are conscious of their sensuality and can look at men in the eye, adding this image to the traditional idea of woman as obedient mother and housewife (Cao \& Pérez 1996), an image that also remains strong in the media and in education. The models that appear in live shows and in the media can be seen as just following the traditional role of sex objects, but a more careful analysis can indicate that female models see their bodies as a way of obtaining resources and power, a way to autonomy and success (Soley-Beltrán 2004, Córdoba 2006). The body acts as a sign of social identity that links individuals with the hegemonic definitions made by social institutions. The social school of symbolic embodiment of acceptable identity and behaviour teaches people how to control the body's appearance (Soley-Beltrán 2004).

A more recent approach is based on advances in evolutionary biology. Biological requirements for a "good body" include characteristics that allow survival, such as sound muscles and senses, and characteristics that favor reproduction, such as a body size that is neither too large nor too small, as well as external indicators of good health, because unhealthy individuals may not be able to produce offspring that successfully reach the reproductive stage.

Some good health indicators are common to both sexes, for example, general body symmetry and a clean skin that reflects a low parasite load (Confer et al. 2010). Other characteristics are sex-specific, such as the wide shoulders, thick arms and aggressiveness that allow males to compete successfully for resources; and the thin waist and full mammary organs that signal fertility in women. Some of these characteristics are not limited to humans and thus cannot be satisfactorily explained by sociological explanations based exclusively on human culture (Confer et al. 2010).

Glamour photography is a form of art that focuses on the beauty of the model's body, with a romantic or erotic view. Normally, the models are young women who can be from fully clothed to nude, but not in sexually explicit poses, and usually they appear on neutral or luxurious backgrounds. Glamour photography must be distinguished from fashion photography, which centers in the clothes and make-up and is associated with high incomes and fame: "models and photographers became the new elite of the beautiful people as well as the heroes of several celebrated films" (Soley-Beltrán 2004).

We were unable to find much scientific literature on the subject of Internet and modeling, so we think this article makes a needed contribution to a relatively new field; we studied how American female glamour models described themselves during the early period of Internet, based on the view presented by Soley-Beltrán (2004), an ex-model who now studies modeling from the approach of the social sciences. Her basic position is that models are not passive "sex objects" but rather, active individuals who see their bodies as a way of obtaining resources and power within the context of their societies (Soley-Beltrán 2004).

\section{METHODOLOGY}

We recorded all the self-descriptions that American female models presented in the website Glamour Models (www.glamourmodels.com), from January 1 through December 31 of 2001. This was the early period of glamour modeling. We selected GlamourModels because it was 
the largest specialized website for American models to offer their services. It allowed models to freely post images, self-descriptions and other information of interest to potential hirers that included individual photographers as well as companies. If the models included links to their websites, we followed them and extracted pertinent additional self-description data.

The data were analyzed from the point of view of five hypotheses that the first author (who is also an art photographer) developed from his 20 years of experience with models:

1. Models see their bodies as the bodies of active individuals with their own skills, ideals and limits.

2. The models describe themselves mostly with socially prescribed characteristics for females such as having good interpersonal relationships and being obedient, instead of "male" characteristics such as being intelligent, professional and creative.

3. The amount of money earned by most glamour models is not enough to cover their expenses, so modeling is just a supplement of their income.

4. The most urbanized states have more glamour models.

5. The conservative "Bible Belt" states have fewer glamour models per capita (Fig. 1 shows the states that we labeled as "Bible Belt State") because glamour modeling has an erotic component that violates conservative views on sexuality.

\section{RESULTS}

\section{Geographic distribution}

Most models were from New York (14), followed by Georgia (5), Maryland and Pennsylvania (4), Kentucky, North Carolina (3), Washington and Tennessee (2 each). There was a model each from Alabama, Kansas, Virginia, Nevada and Illinois. There were no models from the other 38 states (Fig. 1).

\section{Types of modeling that the models accept or reject}

There are 14 statements saying that they do not accept contracts for adult work, i.e. photographs that explicitly show their sex organs, interaction with sexual toys or sexual activities with other people; one states that she does not accept to be recorded in video (Table 1). These are some sample statements:

Please, absolutely no adult-type work and no explicit, Hustler-style nudity. I take my clothes off only when I feel the project is appropriate (Anastasia, New York City)
I do not shoot sexually explicit images. I will not shoot for adult web sites or for anyone providing adult content so please do not ask. (Nicole)

Absolutely no video, toys, girl/girl, boy/girl. (Kassie, Atlanta)

No hard core pornography, live or simulated sex, or similar situations. (Maria, Kansas)

I am not really into the "spread shots" and "porn shots". I've never considered them and don't plan on it. (Aundria, Maryland)

The number of modeling types accepted is greater, and most models stated clearly the types of modeling that they were willing to do, for example:

Tasteful nudes only (Kelly, Pittsburgh, PA)

Fashion, glamour, art, figure, nude and video (Paige R., Atlanta, GA)

TABLE 1

Types of modeling that the models accept and types that they specifically state they do not accept

\begin{tabular}{llc}
\hline \multirow{2}{*}{$\begin{array}{l}\text { Type of modeling } \\
\text { Nude }\end{array}$} & \multicolumn{2}{c}{$\begin{array}{c}\text { Number of } \\
\text { women saying: }\end{array}$} \\
\cline { 2 - 3 } & Yes & No \\
\hline Glamour (may show limited nudity) & 13 & 0 \\
Fashion (clothes, no nudity) & 13 & 0 \\
Artistic (nudity in artistic poses only) & 9 & 0 \\
Figure (artistic nudity in low light settings) & 8 & 0 \\
Fetish & 8 & 0 \\
Video & 5 & 1
\end{tabular}

Additional categories not shown in table because they had few cases, "I accept this type of modeling" statements: other, commercial, playboy style, lingerie (four each); erotic, fitness, swim suit (three each); men magazines, spokesmodels, conventions, runway, hosiery and catalogue (two each); $\mathrm{girl} / \mathrm{girl}$, face, make up, penthouse style, editorial, lifestyle, adult type, comic books, soft core, pay preview, pose without payment in exchange for copies of the photographs ("trade for print" or "TFP") (one "yes" each). 


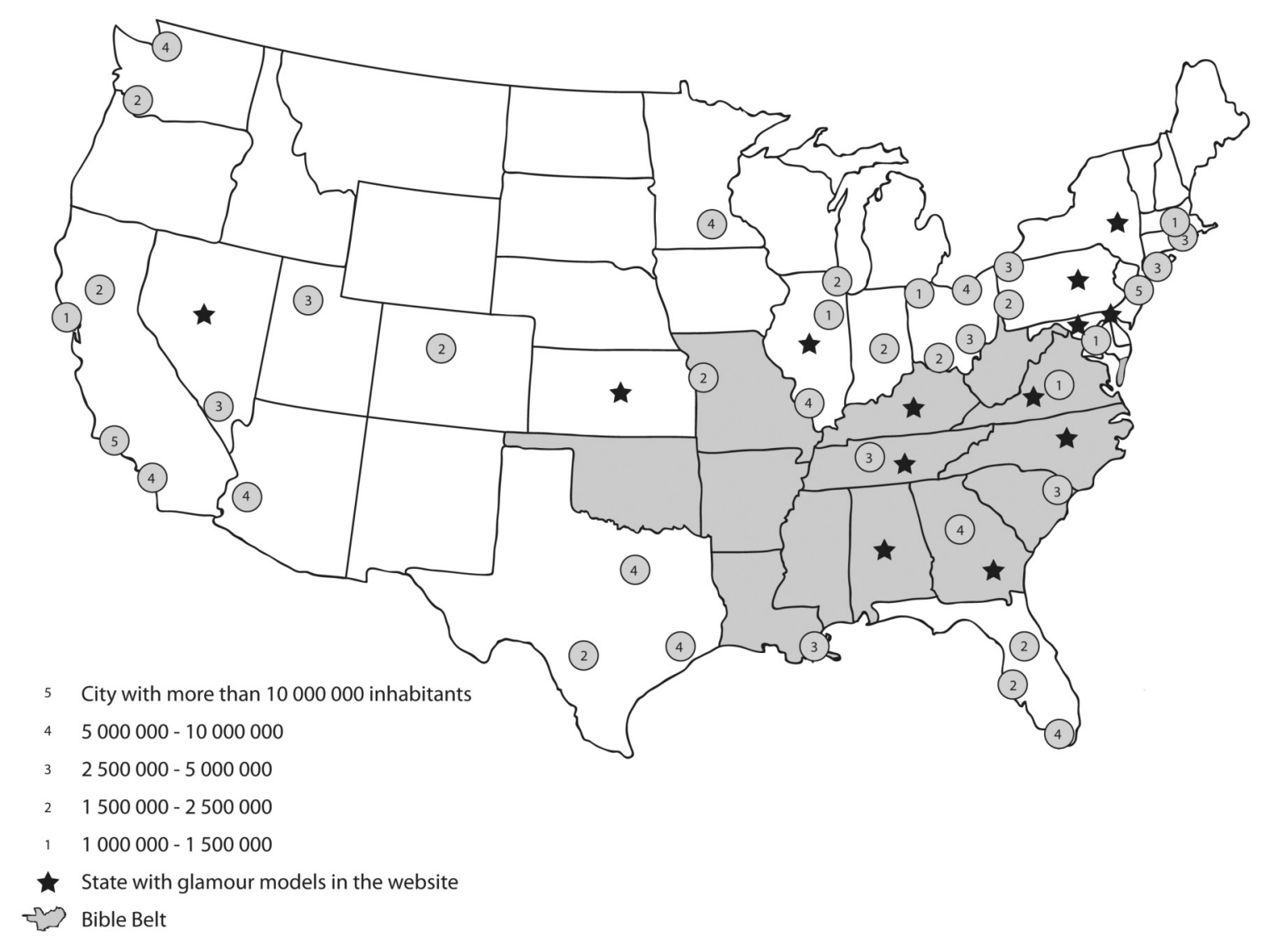

FIG. 1. Geographic distribution of early web glamour models in the USA.

Others were not so clear, stating that they were interested in "many types" or that it depended on how they felt about specific requests, for example:

I am currently accepting any paid assignments I am comfortable with (Christy P. Covington, KY)

I am interested in many styles of modeling, primarily "Playboy style" nudes (Michelle Renae, Louisville, Kentucky)

Nude modeling is where I find myself most comfortable. What do I want to do: Independent films, horror, soft core, pay preview, girl/girl softcore, men's magazines, comic books, fetish. I do try anything once so, if you have an idea, run it by me. (Darian Caine, New York)
Only two stated that they were open to all types of modeling:

I do all/any type of modeling. (Sharon)

I am open to all kinds of work but I particularly enjoy fetish, erotica, and glamour. (Elkie, Washington DC)

Only one of them stated that she was of a more advanced age:

Convention, promotional, commercial, hosiery, catalogue, classic, mature, and is one of the leading mature (age 30+) lingerie catalogue models during the last few years. (Tracey Walker, Chicago) 


\section{Descriptions of their own personalities and bodies}

Most stated that they were easy to work with $(\mathrm{N}=7)$, hard working $(\mathrm{N}=7)$, creative, talented and reliable. Other characteristics were mentioned less frequently: dedicated, versatile, fun and professional ( 2 each); and determinate, charming, experienced, great personality, natural, enthusiastic, intelligent, outgoing, honest and edgy (one each).

Mostly they mentioned that they liked posing $(\mathrm{N}=8)$, working with the photographer (3), the fun of the work, meeting new people (2), success, flexibility and creating images (one each).

They seldom added comments on their bodies to the numerical data that the site required (such as age, height, show size etc.), but those that did mentioned the attractiveness of their face $(\mathrm{N}=2)$, body (2), smile and eyes, fitness and sexy (one each). One example:

I have a lot of talent and a beautiful face. My green eyes, which are clear light green, are my best feature. Especially when the sunlight catches them just right (Penny Clarksville, Tennessee)

They stated that working as glamour models allowed them to enjoy feelings related to what they did and to how they interacted with people:

I enjoy modeling and being in front of the camera because of the absolute freeness it allows me to feel. My body becomes art in the making for any photographer or person watching to enjoy and experience (Lindsay Lee, New Jersey)

I love being on stage or in front of a camera. It gives me a format to express myself in ways I would not be able to in the general public. It gives me a medium for presenting images of beauty and sensuality. Most importantly having a career in the model/fashion industry allows me to do what I love. This is my high! (Kelly Ann, Maryland)

I am very active on a local Model and photographer's Board. Modeling is more difficult than most people realize, but very rewarding. It is a great way to stay motivated to keep in shape! I can create any persona or look that is necessary to meet YOUR needs. I enjoy modeling, and find it to be a creative outlet. Successful projects and worthy images are a result of teamwork between the photographer and the model. This requires a range of flexibility, creativity, professionalism, and a sense of humor. (Ember, Syracuse New York)

I feel like I am a very edgy, creative model. I like to explore and take things and push them a little. I am an artist and musician and I like to take my creative energy into modeling as well. I am very comfortable with my body as well as my moods, I have learned to morph my image to suite the needs of the photographer and or client. I like to create images that stir the mind and the thoughts. I like to make people remember, and to more then just sit there and look like a plastic doll. I am open to almost anything, I do have my limits, but I judge things case by case. So if you have an idea or project, vision or mission and you think I could be a piece let me know. I admire photographers who are willing to explore and to look below the surface.... (Katie, New York)

Others emphasize characteristics that exclude them from the stereotype of female models as women without intelligence, unreliable and ill-tempered:

I have a wonderful friendly smile and great attitude. I have been told by several photographers that I am easy to work with. I have a lot of talent and a beautiful face. (Penny Clarksville, TN)

I am a fun-loving, creative, intelligent, and hardworking college student (Patricia, Pennsylvania)

When I spend time at home from work, I enjoy my computer and the Internet world. I had my computer custom built and I have a large 21-inch monitor (Tracey Walker, Chicago)

One is different because she openly presents an explicit sex-centered description:

If you want variety and you want a hot sexy, big boobed horny shaved blonde pussy to give it to you, then you are home. What turns me on? Two things: Sex with strangers, and sex in front of others. You got it. I'm a fucking horny bitch and I want everyone to watch me fuck, suck and get myself off. I think I'm in the right profession ;) (Anoushka, New York)

\section{Self-fulfillment activities}

In relation with their self view as persons with values, most of the models mention an artistic side and a love for physical activity and nature:

I am also an artist in my spare time. I write poetry. I am still learning to write prose. I do yoga. I play tennis, and I am good at it. I read a lot; I watch movies, like everyone else (Anastasia, New York City)

I enjoy the outdoors, animals, hiking, biking and history. I attend many, cycle/car, horror, glamour; scream queen, video, erotic. I love my home, I love to cook, garden, read, ride my bike, hang out with my animals and family (Darian Caine New York) 
TABLE 2

Hobbies mentioned in early website glamour model self descriptions

\begin{tabular}{lc}
\hline \multicolumn{1}{c}{ Type of hobby } & $\begin{array}{c}\text { Number } \\
\text { of models }\end{array}$ \\
\hline $\begin{array}{l}\text { Outdoor recreation (travel, tennis, sports, } \\
\text { kayaking, biking, sunbathing) }\end{array}$ & 9 \\
$\begin{array}{l}\text { Nightlife (movies, billiards, dancing and karaoke) } \\
\text { Creative hobbies (cooking, decoration, poetry } \\
\text { and writing prose) }\end{array}$ & 5 \\
$\begin{array}{l}\text { Indoor recreation (yoga, computers, aerobics) } \\
\text { nd }\end{array}$ & 3
\end{tabular}

I spend time playing with my four cats, one ferret, a frog, fish and snails... my prairie dog recently passed away but she is missed .... I have had many animals through the years and Love many kinds of animals, maybe someday I will have a Ranch :). I love to read books that are about the human mind, computer and the Internet I love Disco music, Classic rock, Jazz,1980's Music, Mellow Rock and R \& B. I love to have candles lit all over the place, and a bubble bath with a good book and a glass of hot chocolate. :).. My favorite foods are spaghetti, oysters, crab and Mexican food (Tracey Walker, Chicago)

\section{Studies}

In relation with their self-view as more than just sexual images, few of them mention studies, either in course or finished:

I've been going to NYU for four years, studying journalism and politics. I am graduating this May (Anastasia, New York City)

I am also a Make-Up Artist, Internet Graphic Artist, and a Web Developer. I first became interested in computers in high school. I took some basic programming languages and was familiarized with working on PC's. Shorty after high school, though, I started my modeling career, and took some time away from computers. I was reintroduced to computers about 3 years ago to the Internet world of computers, and started learning the basics of the Internet. Shortly afterwards, I started learning some graphics software programs and HTML. I am now designing and developing Internet websites, and thoroughly enjoying it! (Janee Lee, Memphis)

I graduated from one of the top high schools in the state (GO LANCERS!). College brought me to my present home, Maryland. In December 1999, I graduated from the University of Maryland, College Park with a B.S. in Community Health Education and with a certification as a Health Education Specialist (Kelly Ann, Maryland)

\section{Frequency of contracts}

Nicole Lexington from Kentucky, Monica from Alabama and Janeen Lee from Tennessee published their resumes, allowing us to estimate that every year they typically might obtain one contract in a magazine, one as a television extra, one for runway work and one to pose for an art photographer.

\section{DISCUSSION}

\section{Geographic distribution}

Our hypothesis that more conservative states would be under-represented was based on the fact that glamour modeling, unlike other types of modeling, violates the teachings that women from conservative societies receive about sexuality and eroticism (Brown 2005). However, this hypothesis was not supported by our data: despite the low number of models that appeared in the website in those early days, there were several models from the bible belt states, while there were no models from many "non Bible Belt" states (Fig. 1). Our conclusion is that this is a probabilistic phenomenon: states with larger populations have a larger probability of producing glamour models (Fig. 1).

\section{Types of modeling that the models accept or reject}

Our data are in agreement with the hypothesis that models actively see and use their bodies as a way of obtaining resources and autonomy, as stated by Soley-Beltrán (2004) on the basis of her own experience as model and researcher.

\section{Descriptions of their own personalities and bodies}

Our hypothesis that the models describe themselves mostly with socially prescribed "female characteristics" is rejected, because they present themselves in a more complex way, stating that they have both traditionally "male" and "female" behavioral characteristics. This could mean that they describe themselves as expected by the industry (Black 2004, Wissinger 2007, Mears 2010) but rather we think that their descriptions reflect that modeling is seen as a road to success beyond the traditional "dependent female" stereotype (Esteban 2004, Soley-Beltrán 2004, Córdoba 2006). 
A few models can earn millions of dollars per year (Brown 2005) but the women from GlamourModels typically get only four contracts per year (see Results). When they describe why they are in that profession, they mention self-fulfillment rather than money. The importance to self-fulfillment over income can mean that the autonomy and success mentioned by Córdoba (2006) is, for these models, only partially financial. Furthermore, they frequently have an artistic orientation in both their interests and their hobbies, which may explain why they choose to be in an art-related field. Rather than following the traditional western views of men as artists and women as their inspiration (Confer et al. 2010), these women describe themselves as active participants in an artistic act.

We recommend that future studies consider any possible changes from the beginning of the website ten years ago, including whether the models now mention more stereotypically male characteristics in their self descriptions, any changes in their geographic origin, and a greater opening to more sexually explicit modeling.

\section{ACKNOWLEDGMENTS}

We thank Zaidett Barrientos and Megan Rivers-Moore for their valuable comments on an earlier draft, as well as Sergio Aguilar for the map.

\section{REFERENCES}

Black, P. 2004. The Beauty Industry: Gender, Culture, Pleasure. Routledge, New York, USA.

Bordo, S. 1993. Unbearable Weight. Feminism, Western Culture, and The Body. University of California, Berkeley, California, USA.

Brown, J. A. 2005. Class and Feminine Excess: The Strange Case of Anna Nicole Smith. Feminist Review Bodily Interventions
81:74-94 (www.jstor.org/stable/3874342; accessed June 11, 2010).

Cao, M. \& Pérez, C. 1996. La publicidad como reclamo: valores y antivalores sociales. Arte, Individuo y Sociedad 8: 65-83

Confer, J., C. Perillou \& D. Buss. 2010. More than just a pretty face: Men's priority shifts toward bodily attractiveness in short-term versus long-term mating contexts. Evolution and Human Behavior 31: 348-353.

Córdoba, M. 2006. Reseña de "Antropología del cuerpo. Género, intinerarios corporales, identidad y cambio" de Mari Luz Esteban. Revista de Antropología Social 15: 493-496

Davis, K. 2002. "A Dubious Equality: Men, Women and Cosmetic Surgery," Body and Society 8: 49-65.

Esteban, M. 2004. Antropología encarnada. Antropología desde una misma. Papeles del CEIC 12: 4-19

Frost, L. 2001. Young Women and the Body: A Feminist Sociology. Palgrave, New York, USA.

Gimlin, D. 2002. Body Work: Beauty and Self-Image in American Culture. University of California, Berkeley, California, USA.

Jeffreys, S. 2005. Beauty and Misogyny: Harmful Cultural Practices in the West. Routledge, New York, USA.

Lucal, B. 1999. "What it Means to be Gendered Me: Life on the Boundaries of a Dichotomous Gender System." Gender and Society 13: 781-797.

Mears, A. 2010. "Size zero high-end ethnic: Cultural production and the reproduction of culture in fashion modeling." Poetics 38: 21-46.

Schiebinger, L. 1993. Nature's Body: Gender in the Making of Modern Science. Beacon, Massachussetts, USA.

Soley-Beltran, P. 2004. Modeling Femininity. European Journal of Women's Studies 11: 309-326.

Wissinger, E. 2007. Always on Display: Affective Production in the Modeling Industry. In P.T. Clough (ed.). The Affective Turn: Theorizing the Social. Duke University, Durham, North Carolina, USA.

Article edited by Bernal Morera 
